\title{
Epidemiología de malaria en la región Caribe colombiana, 1950-2019
}

\section{Malaria epidemiology in colombian caribbean, 1950-2019}

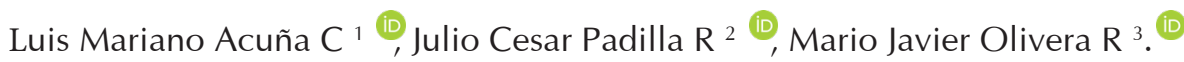

\begin{abstract}
RESUMEN
Objetivo: Establecer el comportamiento epidemiológico de la malaria en la Región Caribe, 1950-2019. Materiales y métodos: Se realizó un estudio observacional descriptivo y retrospectivo, a partir de fuentes secundarias del Ministerio de Salud. Se definieron variables de lugar, persona y tiempo. Se organizó una base de datos de casos de malaria, se estimaron indicadores de frecuencia absoluta, medidas de tendencia central y frecuencia relativa. Resultados: Se registraron 325.427 casos de malaria, las décadas 1950-1959 (33,6\%) y 1980-1989 $(29,3 \%)$ aportaron la mayoría de los casos. El promedio por década fue de 46.489 casos/ década (DE \pm 38.551, M: 25.283), los valores máximos y mínimos fueron 109.416 y 19.525 casos, respectivamente. La distribución por especie fue de 55,8\% (181.663 casos) para Plasmodium vivax y 44,2\% (143.764 casos) para P.falciparum. Los índices parasitarios mediano anual, por P.vivax y por P.falciparum en la fue-
\end{abstract}

ron de 2.2, 1.1 y 0.8 por cada 1000 habitantes respectivamente. Los departamentos que aportaron la mayor carga de casos fueron Bolívar, La Guajira y Magdalena. Conclusiones: El comportamiento secular de la transmisión mostró un patrón endemo-epidémico, de baja y muy baja intensidad de la transmisión, con predominio de infecciones por P.vivax y una frecuencia irregular en la aparición de brotes.

Palabras clave: Comportamiento, Epidemiología, Malaria, Región Caribe, Colombia

Citación (Vancouver): Epidemiología de malaria en la región Caribe colombiana, 1950-2019. Rev Avances en Salud; 2021. (5) $1: 24-25$. doi: $10.21897 / 25394622.2539$

\footnotetext{
'Biólogo, Grupo de Entomología, Dirección de Investigación en Salud Pública - Instituto Nacional de Salud de Colombia INS, Bogotá Colombia. lacuna@ins.gov.co.

${ }^{2}$ Médico Esp, Grupo Staff \& Health S.A.S, Bogotá - Colombia. jcpadilla59@yahoo.es

${ }^{3}$ Médico M.Sc, Grupo de Parasitología, Dirección de Investigación en Salud Pública - Instituto Nacional de Salud de Colombia INS, Bogotá - Colombia. molivera@ins.gov.co.
} 


\section{ABSTRACT}

Objective: Establish malaria epidemiology behavior in Colombian Caribbean, 1950-2019. Methods: A study descriptive, retrospective and observational was conducted of secondary sources information of Ministry Health 19502019. Variables of place, person and time were defined. A malaria cases database was organized, indicators of absolute frequency, measures of central tendency and relative frequency were estimated. Results: The accumulated malaria cases registered were 325.427. The decades 1950-1959 (33.6\%) and 1980-1989 (29.3\%) contributed the highest burden of cases. The average per decade was 46.489 cases/decade (SD $\pm 38,551, M: 25,283)$, the maximum and minimum values were 109.416 and 19.525 cases respectively. The distribution of cases by species was $55.8 \%$ (181.663 cases) for Plasmodium vivax and $44.2 \%$ (143.764 cases) for P.falciparum. The annual parasite incidence, P.falciparum incidence and P.vivax incidence were of 2.2, 1.1 and 0.8 per 1.000 inhabitants respectively. The departments that contributed the highest case load were Bolívar, La Guajira and Magdalena. Conclusions: The secular behavior of transmission showed an endemo-epidemic pattern, of low and very low intensity of transmission, with a predominance of P.vivax infections and an irregular frequency in the appearance of outbreaks.

Key words: Behavior, Epidemiology, Malaria, Caribbean Region, Colombia.

\section{REFERENCIAS}

1. Padilla-Rodríguez JC, Olivera MJ, AhumadaFranco ML, Paredes-Medina AE. Malaria risk stratification in Colombia 2010 to 2019. PLoS ONE. 2021; 16(3): e0247811. https:// doi.org/10.1371/journal.pone.0247811

2. Padilla-Rodriguez JC, Álvarez G, Montoya R, Chaparro P, Herrera S. Epidemiology and control of malaria in Colombia. Mem Inst Oswaldo Cruz. 2011. $106 \quad$ (S1):114-122.https://doi. org/10.1590/S0074-02762011000900015

3. González A. Epidemia de malaria en La Guajira: una muestra lamentable de la situación de salud publica en el país. Biomédica. 2000; 20(2): 151-152. 